\section{Pharmacodynamic behaviour of vecuronium in primary hyperparathyroidism}

This study evaluated the potency and time course of action of vecuronium in patients with primary hyperparathyroidism (HPT) and marked hypercalcaemia during nitrous oxide-opioid anaesthesia. Twenty ASA physical status I and II patients were studied by measuring the force of contraction of the adductor pollicis in response to stimulation of the ulnar nerve: ten control patients and ten patients with HPT and ionized calcium concentration over $2.80 \mathrm{mEq} \cdot \mathrm{L}^{-1}$. After induction of anaesthesia with thiopentone and maintenance with $\mathrm{N}_{2} \mathrm{O} / \mathrm{O}_{2}$ and fentanyl, vecuronium was administered to determine cumulative doseresponse curves. When maximum block had been obtained, twitch height was maintained at $10 \%$ of baseline value over $20 \mathrm{~min}$ by adjusting the infusion rate of a syringe-pump containing vecuronium and vecuronium plasma concentration (EC $\left.C_{90 \mathrm{~s}}\right)$ was determined. During spontaneous recovery, after termination of infusion, the recovery index, the time from 25 to $75 \%$ recovery, was measured. The dose to produce $90 \%$ block was greater in the HPT than in control group: 69 (24) vs 54 (18) $\mu \mathrm{g} \cdot \mathrm{kg}^{-1}(P<0.02)$. The calculated ED 50 was also greater in HPT: 42 (4) vs 31 (5) $\mu \mathrm{g} \cdot \mathrm{kg}^{-1}$ in controls $(P<0.001)$. (Values are given as mean and coefficient of variation). The slope of the dose-response curve, the dose necessary to maintain $90 \%$ block, and the $E C_{90 s s}$ did not differ. The $R_{25-75}$ was slower in the HPT group although the difference did not reach statistical significance. It is concluded that hyperparathyroidism

\section{Key words}

NEUROMUSCULAR RELAXANTS: vecuronium; INTERACTIONS: hyperparathyroidism, hypercalcaemia; PHARMACOKINETICS: dose-response relationships.

From the Department of Anesthesiology and Surgical Intensive Care, Hôpital Universitaire Saint Louis, Paris, France*, and the Research Group for Experimental Anesthesiology and Clinical Pharmacology, University of Groningen, The Netherlands $†$.

Address correspondence to: Dr. Eric Roland, Department of Anesthesiology and Surgical Intensive Care, Hôpital Universitaire Saint Louis, 1 Av Claude Vellefaux, 75010 Paris, France.

Accepted for publication 9th April, 1994.
Eric J.L. Roland MD, ${ }^{*}$ J. Mark K.H. Wierda MD PhD, $\dagger$ Benoit G. Eurin MD, Eric Roupie MD* with hypercalcaemia increases vecuronium requirement; only during the onset of neuromuscular blockade.

Cette étude évalue la puissance et le décours temporel, pendant une anesthésie au protoxyde d'azote-morphinique, du vécuronium chez des patients souffrant d'hyperparathyroïdie primaire (HPT) avec hypercalcémie importante. Vingt patients ASA I et II sont étudiés par la mesure de la force de contraction de l'adducteur du pouce en réponse à une stimulation du nerf cubital: dix patients servent de contrôles à dix patients souffrant d'HPT et dont le concentration de calcium ionisé dépasse 2,80 $m E q \cdot L^{-1}$. Après induction au thiopentone et entretien au $\mathrm{N}_{2} \mathrm{O} / \mathrm{O}_{2}$ avec fentanyl, on administre du vécuronium pour déterminer les courbes cumulatives doses-effets. Après l'obtention d'un bloc maximal, la hauteur du twitch est maintenu à 10\% au-dessus de la ligne de base pendant plus de $20 \mathrm{~min}$ en ajustant la vitesse de perfusion d'un pousse-seringue contenant du vécuronium; on détermine à ce moment la concentration plasmatique de vécuronium ( $E D_{90 s s}$ ). Pendant la récupération spontanée, après l'arrêt de la perfusion, lindex de récupération, la durée requise pour une récupération de 25 à 75\% est mesuré. La dose requise pour produire un bloc à $90 \%$ est plus élevée dans l'HPT que dans le groupe contrôle: 69 (24) vs 54 (18) $\mu \mathrm{g} \cdot \mathrm{kg}^{-1}(P<0,02)$. L'ED $D_{50}$ calculée est aussi plus élevée dans l'HPT: 42 (4) vs 31 (5) $\mu \mathrm{g} \cdot \mathrm{kg}^{-1}$ dans le groupe contrôle $(P<0,001)$. (Les valeurs reproduites sont la moyenne et le coefficient de variation). La pente de la courbe dose-effet, la dose nécessaire au maintien du bloc à $90 \%$ et l'EC $C_{90 s s}$ sont identiques. Le $\mathrm{RI}_{25-75}$ est plus lent dans le groupe HPT mais sans différence statistique. En conclusion, Ihyperparathyroïdie associée à une hypercalcémie importante n'augmente les besoins en vécuronium que pendant lïnstallation du bloc neuromusculaire.

The calcium ion plays an important role in neuromuscular transmission.' Acute changes in concentrations of ionized calcium have been shown to interact on the action of muscle relaxants. Increases in ionized calcium concentrations $\left(\mathrm{Ca}^{++}\right)$in vitro produce decreases in the sensitivity of a nerve muscle preparation to both d-tubocurarine and pancuronium. ${ }^{2}$ In in vivo animal 
experiments, increased $\mathrm{Ca}^{++}$was shown to antagonize the blocking effects of atracurium and vecuronium. ${ }^{3}$

Patients with primary hyperparathyroidism (pHPT) have chronically elevated plasma ionized calcium and decreased phosphate concentrations. The increased extracellular calcium concentration is related to a hypersecretion of parathormone. This hypersecretion may be due to a reduced sensitivity of pathological parathyroid cells to calcium or an increase of the PTH-secreting parathyroid mass. ${ }^{4}$ Patients with neuropathy or neuromuscular disease due to severe pHPT have been described ${ }^{5}$ but the usual presentation of pHPT is an asymptomatic patient, or one with few symptoms, and a moderate hypercalcaemia. ${ }^{6,7}$ In asymptomatic pHPT, neither consistent abnormality of neuromuscular transmission nor abnormal muscle structure were found. ${ }^{6,8}$ However, $\mathrm{Al}^{\prime}$ Mohaya's case report described that the duration of action of atracurium was reduced in a patient with pHPT and high total calcium concentration. ${ }^{9}$ A recent study showed that the magnitude of vecuronium-induced twitch depression was less for patients with pHPT than for control patients. ${ }^{10}$

The effects of prolonged disturbances of calcium homeostasis on vecuronium block are insufficiently known. The present study was designed to examine the hypothesis that the hypercalcaemia induced by hyperparathyroidism would modify vecuronium neuromuscular block.

\section{Methods}

After informed consent and the University Ethics Committee's approval, 20 adult patients aged 21-64 yr, ASA physical status I or II were studied: ten patients had primary hyperparathyroidism with plasma ionized calcium concentration $>2.80 \mathrm{mEq} \cdot \mathrm{L}^{-1}$ and were scheduled for removal of an adenoma or subtotal parathyroidectomy. Ten patients with normal parathyroid function, scheduled for minor surgical procedures served as controls. The study was not blinded. All patients were free from medications or conditions known to affect neuromuscular transmission.

Premedication consisted of $3 \mathrm{mg} \cdot \mathrm{kg}^{-1}$ hydroxyzine po. Anaesthesia was induced with thiopentone 6-8 $\mathrm{mg} \cdot \mathrm{kg}^{-1}$, and fentanyl $2-3 \mu \mathrm{g} \cdot \mathrm{kg}^{-1}$. Tracheal intubation was performed after topical anaesthesia $(3 \mathrm{ml}$ lidocaine $5 \%$ ) without the use of muscle relaxants. Anaesthesia was maintained by inhalation of nitrous oxide $70 \%$ in oxygen and supplemental doses of $1-2 \mu \mathrm{g} \cdot \mathrm{kg}^{-1}$ fentanyl as required. No volatile agents were used. Ventilation was controlled to maintain an end-tidal carbon dioxide tension in the range of $30-35 \mathrm{mmHg}$. Core temperature was kept $>36^{\circ} \mathrm{C}$. Skin temperature was recorded from the studied thenar region and maintained $>34.5^{\circ} \mathrm{C}$.

Cutaneous electrodes were placed at the wrist and neu- romuscular blockade was assessed by measuring the evoked response of the adductor pollicis muscle to supramaximal stimulation of the ulnar nerve by a current constant stimulator. The force of contraction was measured isometrically by a force displacement transducer and recorded on line using the Curametre ${ }^{\oplus}$ (Bio IndustryFrance). Square-wave pulses of $0.2 \mathrm{~ms}$ duration (single twitch) were delivered every ten seconds during the onset of neuromuscular block. During spontaneous recovery TOF (TOF, four stimuli with a frequency of $2 \mathrm{~Hz}$ ) impulses were applied every $20 \mathrm{sec}$. Resting thumb adductor tension was maintained between 200 and $300 \mathrm{~g}$ throughout the study.

After stabilization of the control twitch height for at least 10 minutes, arterial blood samples were collected for blood gas analysis, plasma ionized and total calcium, phosphate, potassium, magnesium, plasma proteins and haematocrit. The ionized calcium concentration was measured by an analyzer with a calcium specific electrode (Radiometer@-Copenhaguen). Then, the dose-response part of the study was performed using a cumulative technique. Initially, vecuronium $20 \mu \mathrm{g} \cdot \mathrm{kg}^{-1}$ were given as a bolus. Once the maximum effect of the selected initial dose was reached, additional doses of $10 \mu \mathrm{g} \cdot \mathrm{kg}^{-1}$ were given when the maximum effect had been obtained until approximately $95 \%$ twitch height depression was obtained. In case no effect was obtained within $2.5 \mathrm{~min}$ after the initial dose - that is when no decrease in evoked twitch height occurred after at least 15 consecutive single twitches - a supplementary dose of $10 \mu \mathrm{g} \cdot \mathrm{kg}^{-1}$ vecuronium was administered as a divided initial dose.

Hereafter twitch height was maintained at $10 \%$ of baseline value by manually adjusting the infusion rate of a syringe-pump containing vecuronium $0.1 \mathrm{mg} \cdot \mathrm{ml}^{-1}$ in saline $(\mathrm{NaCl} 0.9 \%)$. The dose requirement was noted and vecuronium plasma concentration $\left(\mathrm{EC}_{90 \mathrm{ss}}\right)$ was determined after at least $20 \mathrm{~min}$ of unchanged block and infusion rate. During spontaneous recovery, after termination of infusion, the time interval between 75 and $25 \%$ block $\left(\mathrm{RI}_{25-75}\right)$ was measured.

For the determination of plasma concentration of vecuronium, $4 \mathrm{ml}$ blood samples were withdrawn into lithium heparinized tubes from an arterial line after the end of the infusion period. Samples were immediately acidified by the addition of $1 \mathrm{ml} \mathrm{NaH} \mathrm{PO}_{4}, 1 \mathrm{M}$. The plasma was separated within one hour and deep frozen until analysis by high performance liquid chromatography (HPLC). ${ }^{5}$ The concentrations of vecuronium and its putative metabolites has been determined by an HPLC method described for rocuronium, modified and validated for vecuronium. " After extraction from plasma, compounds were separated by HPLC followed by postcolumn ion-pair extraction and fluorometric detection. 
The method shows a linear relationship between the logarithm of the response ratio (peak height compound/ peak height interval standard) ranging from 5-1000 ng for vecuronium and its metabolites, showing an intraday variability of $4.7-1.5 \%, 2.6-2.7 \%$, and 9.7 and $2.8 \%$ for vecuronium, 3-desacetyl vecuronium and 3,17didesacetyl vecuronium respectively, whereby $100-1000$ $\mu l$ plasma can be processed. The accuracy, expressed as percentages found of the added amount are $105 \%, 99 \%$, $104 \%$ and $95 \%$ for $10,100,500,1000 \mathrm{ng} \cdot \mathrm{ml}^{-1}$ vecuronium respectively. For 3-desacetyl vecuronium the accuracy amounts to $112 \%, 105 \%, 99 \%$, and $87 \%$, whereas for 3,17-didesacetyl vecuronium the accuracy amounts to $115 \%, 108 \%, 85 \%$, and $105 \%$ for the afore-mentioned concentrations respectively. The lower limit of quantification, defined as the minimum concentration, which can be determined with an accuracy and precision better than $15 \%$ is $5 \mathrm{ng} \cdot \mathrm{ml}^{-1}$ for all three compounds.

A log-logit analysis of the dose-response data during onset of block was performed for each patient. Individual dose-response regression lines were calculated. These lines were characterized by the effective doses at $50 \%$ block $\left(\mathrm{ED}_{50}\right)$ calculated by interpolation, and the corresponding slopes.

All values are given as mean values with the coefficient of variation (\%) in brackets [CV $=(\mathrm{SD} /$ mean) $100 \%]$. The results were analyzed using the Mann-Whitney Utest. Differences were considered significant at $P<0.05$.

\section{Results}

The age of the patients ranged from 18 to $61 \mathrm{yr}$ and 24 to $54 \mathrm{yr}$ in the control and HPT groups respectively. Both groups were comparable with respect to age, male/ female distribution, weight, body surface area, plasma proteins, blood gases, haematocrit and plasma concentrations of magnesium and potassium. Plasma phosphate (normal range: $0.75-1.25 \mathrm{mmol} \cdot \mathrm{L}^{-1}$ ) and plasma ionized calcium (normal range: $2.2-2.6 \mathrm{mEq} \cdot \mathrm{L}^{-1}$ ) and total calcium concentrations (normal range: 2.2-2.6 $\mathrm{mmol} \cdot \mathrm{L}^{-1}$ ) were different between the two groups (Table I).

The cumulative dose-response curves were completed in 20 (25) and 18 (16) $\mathrm{min}$ for the HPT and control group respectively (NS). More dose increments were required to produce equivalent block, 5.9 (27) vs 4.4 (21) $(P<0.02)$, in the HPT group than in the control group. Consequently the total cumulative dose of vecuronium to achieve $90 \%$ block was higher in the HPT group than in the control group, 69 (24) vs 54 (18) $\mu \mathrm{g} \cdot \mathrm{kg}^{-1}$ respectively $(P<0.02)$.

The dose-response curve for patients with hyperparathyroidism showed a shift to the right compared with that for the control group, as can be deduced from the
TABLE I Characteristics of the two groups of patients. Data are presented as mean values and coefficients of variation $(\%)$ in parentheses $(\mathrm{CV})$

\begin{tabular}{llll}
\hline & HPT group & Control group & $P$ \\
\hline$n$ & 10 & 10 & \\
$\mathrm{M} / \mathrm{F}$ & $2 / 8$ & $3 / 7$ & $\mathrm{NS}$ \\
Age (yr) & $44(36)$ & $39(33)$ & $\mathrm{NS}$ \\
Weight $(\mathrm{kg})$ & $54.7(19)$ & $58.5(10)$ & $\mathrm{NS}$ \\
Body surface area $\left(\mathrm{m}^{2}\right)$ & $1.58(11)$ & $1.56(6)$ & $\mathrm{NS}$ \\
& & & \\
Ca & & & \\
Total calcium $\left(\mathrm{mmol} \cdot \mathrm{L}^{-1}\right)$ & $3.18(11)$ & $2.45(3)$ & $<0.01$ \\
$\mathrm{PO}_{4}\left(\mathrm{mmoles} \cdot \mathrm{L}^{-1}\right)$ & $0.72(19)$ & $1.19(18)$ & $<0.01$ \\
\hline
\end{tabular}

TABLE II Summary of data obtained in the study. Results are presented for the group of patients with hyperparathyroidism (HPT) and for the control group. Data are presented as mean values and coefficients of varation (\%) in brackets (CV). For the abbreviations of the variables see the explanation in the Results section

\begin{tabular}{llll}
\hline Parameter & HPT group & Control group & $P$ \\
\hline $\mathrm{ED}_{90}\left(\mu \mathrm{g} \cdot \mathrm{kg}^{-1}\right)$ & $69(24)$ & $54(18)$ & $<0.02$ \\
$\mathrm{ED}_{50}\left(\mu \mathrm{g} \cdot \mathrm{kg}^{-1}\right)$ & $42(04)$ & $31(05)$ & $<0.001$ \\
Slope $_{\mathrm{dr}}$ & $4.96(17)$ & $4.41(17)$ & $\mathrm{NS}$ \\
Inf.rate $_{90 \mathrm{ss}}\left(\mu \mathrm{g} \cdot \mathrm{kg}^{-1} \cdot \mathrm{hr}^{-1}\right)$ & $112(26)$ & $108(20)$ & $\mathrm{NS}$ \\
$\mathrm{EC}_{90 \mathrm{ss}}\left(\mu \mathrm{g} \cdot \mathrm{L}^{-1}\right)$ & $298(09)$ & $299(06)$ & $\mathrm{NS}$ \\
$\mathrm{RI}_{25-75}(\mathrm{~min})$ & $12.3(39)$ & $9.8(19)$ & $\mathrm{NS}$ \\
\hline
\end{tabular}

increase of the calculated value of the dose producing $50 \%$ block $\left(\mathrm{ED}_{50}\right)$. The parallelism of the curves is suggested by the absence of a difference in the slopes of the line of the log-logit dose-response relationship of both groups (Table II).

Drug infusion requirements for maintaining a block of $90 \%$ for at least $\mathbf{4 0} \mathrm{min}$ after the first administration of vecuronium and following $20 \mathrm{~min}$ at an unchanged rate of infusion were not different between the two

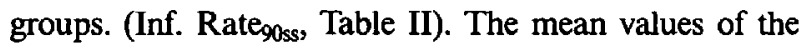
plasma vecuronium concentrations at the end of the constant infusion period, corresponding to a $90 \%$ twitch height depression, were almost identical (EC $\mathrm{EC}_{9 \mathrm{ss}}$, Table II). In one patient we failed to obtain a plasma sample at $90 \%$ block and this patient was consequently excluded from the $\mathrm{EC}_{90 \text { ss }}$ determination.

In the HPT group, a higher mean value and a wider range of recovery indices were obtained but the difference did not reach the level of significance (Table II).

\section{Discussion}

This study was designed to evaluate the influence of primary hyperparathyroidism with chronic hypercalcaemia on the potency and the time course of action of vecur- 
onium. The results showed that, initially, a higher dose is needed to obtain a similar degree of block in HPT patients. The dose-response relationships were established in the absence of inhalational agents - which are known to potentiate the effect of vecuronium..$^{12}$ The parallel shift to the right of the dose-response curve is in accordance with the findings of Caldwell et al., who showed that the magnitude of vecuronium-induced twitch depression was less for the patients with primary HPT than for control patients. ${ }^{10}$

In the present study, the cumulative dose technique was used to assess the potency of vecuronium. The last dose of vecuronium was administered more than $12 \mathrm{~min}$ after the first dose. D'Hollander et al., using a similar cumulative dose technique, found an $\mathrm{ED}_{50}$ and an $\mathrm{ED}_{90}$ at 37 and $56 \mu \mathrm{g} \cdot \mathrm{kg}^{-1}$ respectively. ${ }^{13}$ These findings are comparable with the results obtained in the control patients in the present study. For muscle relaxants with an intermediate time-course of action, it is known that this cumulative method may lead to overestimation of the effective dose, when given as a bolus, due to redistribution taking place during the determination of the doseresponse curve. Nevertheless the method remains valid when used to compare neuromuscular blocking effects between two groups. ${ }^{14,15}$

Plasma concentrations at the end of infusion were almost identical for similar degrees of neuromuscular block. During pseudo steady-state conditions, as reached in our study at the end of the infusion period, plasma concentrations should reflect the concentration of vecuronium in the effect compartment. This was shown earlier by d'Hollander et al. ${ }^{16}$ and could be confirmed by pharmacokinetic simulation of our study design using the pharmacokinetic data of Sohn et al. ${ }^{17}$ Based on these results it is difficult to explain differences in potency $\left(\mathrm{ED}_{90 \mathrm{cum}}\right)$ by differences in sensitivity $\left(\mathrm{EC}_{90 \mathrm{ss}}\right)$. Pharmacokinetic factors, associated with simultaneous increases of the $\mathrm{ED}_{90 \mathrm{cum}}$ dose and the recovery index, may be involved, such as an increase in the (initial) volume of distribution in patients with hyperparathyroidism. Further pharmacodynamic-kinetic modelling studies may be helpful to elucidate the mechanisms involved, since modelling enables us to discriminate between pharmacodynamic and pharmacokinetic factors.

The recovery was somewhat slower in the HPT group although the difference did not reach statistical significance. The absence of a statistical difference in recovery index between the two groups may probably be based on a type II error. This could be the consequence of a larger variation of recovery indices in the HPT group, which hampered detection of statistical differences between groups with a limited number of patients.

The only differences in electrolyte values between the two study groups were hypercalcaemia and hypophosphataemia in the HPT group. In both groups, electrolyte status and intravascular volume - as assessed by plasma proteins, urea concentrations, and by haematocrit - were normal. Low concentrations of phosphate in plasma may impair neuromuscular function, although interactions with neuromuscular blockers are unknown. ${ }^{18}$ The effects of varying calcium concentration on a vecuroniuminduced block have been reported previously. Using an isolated guinea-pig nerve-lumbrical muscle preparation, Waud has shown that increases in concentration of ionized calcium decrease the sensitivity of the preparation to d-tubocurarine and pancuronium. ${ }^{2}$ In another study, Gramstad et al. have determined the neuromuscular blocking effects of vecuronium at high plasma concentrations of ionized calcium in the cat in vivo: an acute increase in $\mathrm{Ca}^{++}\left(2.42 \mathrm{meq} \cdot \mathrm{L}^{-1}\right.$ to $\left.3.18 \mathrm{meq} \cdot \mathrm{L}^{-1}\right)$ antagonized an already established vecuronium neuromuscular block of vecuronium, but the size of interaction (increased $\mathrm{ED}_{50}$ by 7-13\%) was considered clinically insignificant. ${ }^{3}$

These laboratory data were obtained following acute changes of calcium ion concentration in other species. In contrast, in primary HPT, the chronic hypercalcaemia might also lead to other processes aimed at counteracting the effects of the increased calcium levels to maintain homeostasis.

In conclusion, this study shows that patients with primary HPT are more resistant to an initial dose of vecuronium than normal patients and that the effective doses to obtain 50 and $90 \%$ block $\left(\mathrm{ED}_{50}\right.$ and $\left.\mathrm{ED}_{90}\right)$ in these patients are respectively 1.35 and 1.3 times higher than in patients with normal parathyroid function. The resistance of patients with primary HPT cannot be explained fully by pharmacodynamic differences, since the concentration of vecuronium at $90 \%$ neuromuscular block $\left(\mathrm{EC}_{90 \mathrm{ss}}\right)$ in these patients is similar to that in control patients with normocalcaemia.

\section{Acknowledgement}

The authors wish to thank J.H. Proost PhD for his invaluable assistance.

\section{References}

1 Miller RD. Factors affecting the action of muscle relaxants. In: Katz RL (Ed.) Muscle Relaxants, Amsterdam: North Holland Publishing Co., 1975; 163-91.

2 Waud BE, Waud $D R$. Interaction of calcium and potassium with neuromuscular blocking agents. $\mathrm{Br} \mathrm{J}$ Anaesth 1980; 52: 863-6.

3 Gramstad L, Hysing ES. Effect of ionized calcium on the neuromuscular blocking actions of atracurium and vecuronium in the cat. Br J Anaesth 1990; 64: 199-206. 


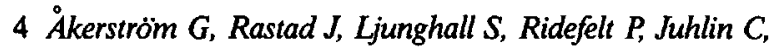
Gylfe $E$. Cellular physiology and pathophysiology of the parathyroid glands. World J Surg 1991; 15: 672-80.

5 Patten B, Bilezikian J, Mallette L, Prince A, Engel WK, Aurbach $G D$. Neuromuscular disease in primary hyperparathyroidism. Ann Intern Med 1974; 80: 182-93.

6 Harrison B, Wheeler $M H$. Asymptomatic primary hyperparathyroidism. World J Surg 1991; 15: 724-9.

7 Ljunghall S, Hellman P, Rastad J, Åkerström G. Primary hyperparathyroidism: epidemiology, diagnosis and clinical picture. World J Surg 1991; 15: 681-7.

8 Jansson S, Grimby G, Hagne I, Hedman I, Tisell L-E. Muscle structure and function before and after surgery for primary hyperparathyroidism. Eur J Surg 1991; 157: 13-6.

9 Al-Mohaya S, Naguib M, Abdelatif $M$, Farag $H$. Abnormal responses to muscle relaxants in a patient with primary hyperparathyroidism. Anesthesiology 1986; 65: 554-6.

10 Caldwell JE, Heier T, Miller RD. Hyperparathyroidism and vecuronium-induced neuromuscular blockade. Anesthesiology 1989; $71:$ A814.

11 Kleef UW, Proost JH, Roggeveld J, Wierda JMKH. Determination of rocuronium and its putative metabolites in body fluids and tissue homogenates. J Chromatogr 1993; 621: 65-76.

12 Rupp SM, Miller RD, Gencarelli PJ. Vecuronium-induced neuro-muscular blockade during enflurane, isoflurane, and halothane anesthesia in humans. Anesthesiology 1984; 60: 102-5.

13 d'Hollander A, Agoston S, Capouet V, Barrais L, Bomblet $J P$, Esselen $M$. Failure of metronidazole to alter a vecuronium neuromuscular blockade in humans. Anesthesiology 1985; 63: 99-102.

14 Fisher DM, Fahey $M R$, Cronnelly $R$, Miller RD. Potency determination for vecuronium (ORG NC45): comparison of cumulative and single-dose techniques. Anesthesiology 1982; 57: 309-10.

15 Gibson FM, Mirakhur RK, Clarke RSJ, Lavery G. Comparison of cumulative and single bolus dose techniques for determining the potency of vecuronium. $\mathrm{Br} \mathrm{J}$ Anaesth 1985; 57: 1060-2.

16 d'Hollander A, Massaux $F$, Nevelsteen M, Agoston $S$. Age-dependant dose-response relationship of ORG NC45 in anaesthetized patients. Br J Anaesth 1982; 54: 653-7.

17 Sohn YJ, Bencini AF, Scaf AHJ, Kersten UW, Agoston S. Comparative pharmacokinetics and dynamics of vecuronium and pancuronium in anesthetized patients. Anesth Analg 1986; 65: 233-9.

18 Brautbar N, Kleeman CR. Hypophosphatemia and hyperphosphatemia: clinical and pathophysiologic aspects. In: Maxwell MH, Kleeman CR, Narins RG (Eds.). Clinical Disorders of Fluid and Electrolyte Metabolism, 4th ed. New York: McGraw-Hill, 1987: 789-830. 